\title{
MÍDIA E RELAÇÕES ÉTNICO-RACIAIS: A QUESTÃO DOS AFRODESCENDENTES NA TELEVISÃO BRASILEIRA. ${ }^{1}$
}

\section{Viviane Rodrigues Darif Saldanhas ${ }^{2}$}

Resumo: O presente artigo propõe apresentar, de forma sucinta, como os meios de comunicação de massa, em especial a televisão brasileira, permanecem demonstrando certa invisibilidade e esteriotipação em relação aos afrodescendentes ${ }^{3}$. Para tanto, foi realizada uma análise bibliográfica em perspectiva sociológica em relação á indústria cultural de massa, a cultura da mídia e o papel do negro na televisão brasileira. Este artigo foi realizado com a intenção de tentar compreender se e como a mídia demonstra a diversidade cultural brasileira.

Palavras-chave: mídia; televisão; relações étnico-raciais.

\footnotetext{
Trabalho apresentado de forma oral na modalidade Artigo Científico na IV Conferência Sul-Americana e IX Conferência Brasileira de Mídia Cidadã.

2 Bacharela e licenciada em Ciências Sociais e mestranda em Sociologia pela Universidade Federal do Paraná (UFPR). BolsistaCAPES. E-mail: vivianedarif@gmail.com
${ }^{3}$ A utilização dessa palavra para designar a parte da população negra ou parda se deve ao fato de que "[...] a dimensão do termo afrodescendente é extremamente ampla e abrangente. $\mathrm{O}$ seu emprego acaba instando às nações a uma revisão das relações estabelecidas historicamente com os povos originários do continente africano espalhados na diáspora." (ROCHA, 2010, p.904).




\section{INTRODUÇÃO}

Vivemos em uma sociedade globalizada ${ }^{4}$ e tecnológica, na qual os meios de comunicação vêm ganhando cada vez mais espaço e exercendo poder sobre as diversas dimensões da vida do ser humano, seja no aspecto social, político ou econômico. Utilizando-se desses meios de comunicação, que são os encarregados de difundir as produções culturais produzidos por ela, a mídia torna-se capaz de atingir diferentes públicos de diversas maneiras, exercendo influencias cada vez mais significativas na vida cotidiana.

Os indícios do poder demonstrado pelos meios de comunicação de massa são evidentes e mesmo uma pequena parcela da população que não possui tais acessos diretos, não está isenta ao bombardeio de informações midiáticas que estes oferecem. Esses acessos são disponibilizados de diversas maneiras, sejam através de outdoors, vitrines de lojas onde televisores ficam ligados simultaneamente, jornais e revistas expostos em bancas, dentre outras.

Numa cultura contemporânea dominada pela mídia, os meios dominantes de informação e entretenimento são

\footnotetext{
4 “A globalização pode assim ser definida como a intensificação das relações sociais em escala mundial, que ligam localidades distantes de tal maneira que acontecimentos locais são modelados por eventos ocorrendo a muitas milhas de distância e vice-versa" (GIDDENS, 1991, p.69).
} 
uma fonte profunda e muitas vezes não percebidas de pedagogia cultural: contribuem para nos ensinar a como nos comportar e o que pensar e sentir, e em que acreditar o que temer e o que desejar - e o que não. (KELLNER, 2001, p. 10).

Belloni (2005) afirma que além de serem caracterizadas principalmente pelo avanço tecnológico e pela globalização, as mídias também se apresentam como dispositivos complexos com claras tendências estruturais à padronização de conteúdos. Além disso, possui uma eficiência singular no quesito econômico e relativo à comunicação, auxiliando na reprodução de estruturas simbólicas da sociedade e operando como meio eficaz de tanto na construção quanto na perpetuação da hegemonia de um grupo dominante.

Ou seja, além de cumprir um papel como um agente de informação, a mídia também age como sendo uma formadora de opinião, conforme assinala Rondelli, “... os meios de comunicação não só moldam o que pensamos sobre a realidade exterior, mas define, sobretudo, uma pauta daquilo sobre o que é necessário ter uma opinião e discutir" (1997, p. 155).

Podemos observar esse fato de maneira bastante latente na cultura da sociedade contemporânea, observando através da perspectiva construída pela Teoria Crítica Social, caracterizada pelo conceito 
explicativo de Indústria Cultural de Massa, proposta por Adorno e Horkeimer (2002).

\section{INDÚSTRIA CULTURAL E MÍDIA}

A partir dos anos 1930 "a escola de Frankfurt inaugurou os estudos críticos de comunicação e cultura de massa e desenvolveu um primeiro modelo de estudo cultural" (KELLNER, 2001, p.43). Esta escola foi criada a partir da iniciativa de um grupo de pensadores alemães em formarem o Instituto de Pesquisa Social de Frankfurt, na Alemanha. O modelo de estudo cultural proposto pela escola de Frankfurt foi concebido através da combinação da análise cultural de estudos acerca da recepção e efeito sociais e ideológicos da cultura e dos meios de comunicação de massa. O objetivo desse instituto era proceder a um exame crítico da sociedade, em geral, e em seus aspectos econômicos, culturais e de produção de conhecimento, a partir de uma perspectiva marxista renovada, isto é sem estar presa, ao historicismo ou ao materialismo.

A escola de Frankfurt apresentou diversos pensadores, mas nos focaremos em Theodor Adorno e Max Horkheimer, que foram os criadores de um conceito base para os estudos culturais acerca da 
indústria cultural, onde apontaram um novo conceito com relação à cultura e a massificação da mesma.

Na visão de Adorno e Horkheimer (1985) a cultura para a massa não passava de uma industrialização da cultura, ou seja, a tecnologia sendo utilizada como um instrumento no desenvolvimento e consolidação das formas de controle das concepções sociais, estando a serviço da dominação ideológica estruturadas na sociedade capitalista.

\begin{abstract}
Os teóricos críticos analisavam todas as produções culturais de massa no contexto da produção industrial, em que os produtos das indústrias culturais apresentavam as mesmas características dos produtos fabricados em massa: transformação em mercadoria, padronização e massificação. Os produtos das indústrias culturais tinham a função específica, porém, de legitimar ideologicamente as sociedades capitalistas existentes e de integrar os indivíduos nos quadros da cultura de massa e sociedade (KELLNER, 2001, p. 44).
\end{abstract}

Dessa maneira, formularam o conceito de indústria cultural, que seria um mecanismo de massificação da opinião, dos gostos e da necessidade de consumo. Na indústria cultural tudo passa a ser um produto de mercado, inclusive o ser humano, a verdadeira preocupação não é transmitir informações ou conhecimento, mas sim vender cada vez mais produtos e idéias homogeneizadas, a fim de se obter o lucro acima de tudo, além de impedir "a formação de indivíduos autônomos, 
independentes, capazes de julgar e de decidir conscientemente" (Adorno, 1986, p. 99).

Essa cultura se constitui por sistemas baseados no modelo de produção de massa e para a massa, ou seja, ela é uma cultura comercial, produzida com a intenção de atrair audiência, visando lucro e acumulação de capital.

A arte, a música, a literatura se transformam em meros produtos com o objetivo de serem difundidos comercialmente, perde-se o valor e a essência da criação cultural, isto não seria o mais importante, o que realmente importaria seria rotular e vender o produto. A indústria cultural gera "produtos adaptados ao consumo das massas e que em grande medida determinam esse consumo" (ADORNO, 1986, p. 91).

Dentro da indústria cultural, para que o mercado atinja o seu principal objetivo que é o lucro, existe uma peça fundamental que é a alienação do povo. É dela que a indústria cultural se aproveita para massificar os seus produtos e ao massificar os gostos e necessidades de consumo, o mercado aprofunda a alienação, e com isso cria-se a passividade e o conformismo.

Na medida em que nesse processo a indústria cultural inegavelmente especula sobre o estado de consciência e inconsciência de milhões de pessoas às quais ela se dirige, as massas não são, então, o fator primeiro, mas um 
elemento secundário, um elemento de cálculo; acessório da maquinaria. $\mathrm{O}$ consumidor não é rei, como a indústria cultural gostaria de fazer crer, ele não é o sujeito dessa indústria, mas seu objeto. (ADORNO, 1986, p.93).

Esse procedimento observado fornece elementos para a compreensão quanto ao processo de industrialização da cultura produzida para a massa, ou seja, transformação da cultura em mercadoria, instituindo a expressão indústria cultural.

Desse modo, a ideologia cultural começou a ser dirigida pela falsa necessidade de consumo e obrigação de lucro a todo custo, impostas pelo capitalismo. Em virtude disso, as mercadorias culturais produzidas e originadas sob os desígnios da indústria cultural apontam nitidamente para a mercantilização, ocorrência que interfere diretamente nos conteúdos e processos de criação das obras.

Do mesmo modo, essa comercialização da cultura contribui para a domesticação das manifestações e da cultura popular das classes subordinadas. Dessa forma, a indústria cultural também resulta no isolamento dos indivíduos, dando cabo na racionalidade, uma vez que, através da submissão à publicidade e ao consumo dos mesmos produtos demonstra que a liberdade de escolha nada mais é que uma mera ilusão.

Segundo Adorno e Horkheimer (1985), a indústria cultural colabora para o processo de servidão tanto do corpo quanto do espírito, 
da mesma forma que o desencadeado pelo sistema de trabalho. Nesse sentido, o papel do homem na indústria cultural é de mero objeto, servindo apenas de instrumento de trabalho e de consumo. Isso faz com que o homem seja tão manipulado e ideologizado que mesmo momentos de lazer e divertimento tornam-se uma extensão do trabalho.

\begin{abstract}
A diversão é o prolongamento do trabalho sob o capitalismo tardio. Ela é procurada por quem quer escapar ao processo de trabalho mecanizado, para se por de novo em condição de enfrentá-lo. Mas, ao mesmo tempo, a mecanização atingiu um tal poderio sobre a pessoa em seu lazer e sobre sua felicidade, ela determina tão profundamente a fabricação das mercadorias destinadas à diversão, que esta pessoa não pode mais perceber outra coisa senão as cópias que reproduzem o próprio processo de trabalho (ADORNO e HORKHEIMER, 1985, p.1819).
\end{abstract}

Para Adorno e Horkheimer (1985), essa diversão disponibilizada pela indústria cultural tem como objetivo a integração das massas ao sistema capitalista, auxiliando na geração de fragmentação e impotência. Uma vez que essa diversão isola e afasta o individuo, colaborando para aprofundar a condição alienada das massas e impedindo a formação de indivíduos capazes de refletir autonomamente. 
Portanto, podemos considerar a Indústria Cultural como sendo uma ideologia que visa obscurecer a percepção do indivíduo, de forma que valores sociais passem a ser regidos, influenciados e condicionados por ela. Desse modo, podemos perceber que a cultura, sob as regras da indústria cultural, passa a ser apenas uma mercadoria, um produto a ser vendido e explorado comercialmente, que também atua impedindo a formação de indivíduos autônomos, independentes e capazes de julgar e decidir conscientemente.

\section{CULTURA DA MÍDIA}

O conceito de indústria cultural desempenha um importante papel nos estudos culturais e mostra-se uma das teorias que mais fornece aparatos para a análise da cultura da mídia, já que se encontra centrada na articulação entre cultura, tecnologia e ideologia. Além disso, analisar o conceito de ideologia é de suma importância para a construção da análise dos produtos da cultura da mídia, e, portanto fundamental na avaliação acerca dos programas infantis.

Em virtude de tais contribuições, principalmente no que se refere á comunicação de massa, ocorreram diversas mudanças que 
provocaram grandes impactos nas sociedades modernas, tanto no que diz respeito à natureza da cultura quanto da ideologia.

Devido estas transformações, segundo Kellner (2001), a análise da ideologia não poderia mais se limitar apenas ao exame de doutrinas políticas e economicistas, que a reduziam aos interesses da classe capitalista, mas também compreender as distintas formas simbólicas existentes no mundo social, ou seja, o modo como são produzidas e reforçadas a massificação do indivíduo e a maneira como são estruturadas as relações sociais.

Kellner (2001) verificou que o modelo que era caracterizado exclusivamente pelos interesses de classe acabou sendo contestado por diversos críticos, em virtude de não considerar aspectos como a raça, sexo, dentre outras maneiras de dominação ideológica. Já que:

reduzir ideologia a interesses de classe deixa claro que a única dominação importante na sociedade é a de classe, ou a econômica, ao passo que, segundo muitos teóricos, a opressão de sexo, sexualidade e raça também são de fundamental importância e, na verdade, ainda de acordo com alguns, está inextricavelmente imbricada na opressão econômica e de classe. (KELLNER, 2001, p. 79).

Além disso, Kellner (2001) aborda outro aspecto da ideologia: a inferência na sociedade. Uma vez que segundo o autor, a ideologia 
pressupõe a idéia de uma norma que geralmente referem-se ao branco masculino, ocidental, de classe média ou superior e onde todos que são diferentes a ela são considerados não normais, ou seja, raças, classes, grupos e sexos diferentes são inferiores e/ou secundários. Dessa forma, ela [ideologia] "diferencia e separa grupos em dominantes/dominados e superiores/inferiores, produzindo hierarquias e classificações que servem aos interesses das forças e elites de poder" (KELLNER, 2001, p.83).

Segundo Thompson (2002) essas relações de dominação e poder que atinge a grande parte das pessoas, de forma mais direta, são as caracterizadas pelos contextos sociais onde estão inseridas cotidianamente e que passam a maior parte do tempo interagindo, como a escola, trabalho, família, dentre outros.

Entretanto, em virtude dos discursos midiáticos ocuparem um lugar privilegiado na estruturação das relações de dominação e através da cultura da mídia, os indivíduos passaram a ser submetidos há formas distintas de socialização, não mais decorrentes apenas das instituições sociais tradicionais, como família, escola, religião ou trabalho.

Kellner (2001) afirma que os meios dominantes de entretenimento e informação tornam-se grandes colaboradores no adestramento de comportamentos, pensamentos, crenças, sentimentos e 
até em mesmos temores e desejos. Para ele, a cultura da mídia auxilia no estabelecimento de hegemonia de determinados grupos ao produzir representações que visam induzir a anuência a certos valores, levando os membros da sociedade a reproduzirem ideologias.

Uma vez que a cultura da mídia "reproduz as lutas e os discursos sociais existentes, expressando os medos e os sofrimentos da gente comum, ao mesmo tempo fornece material para a formação de identidades e dá sentido ao mundo" (KELLNER, 2001, p.203).

Além disso, de acordo com Thompson (2002) essa ideologia opera a partir do momento em que as produções culturais simbólicas de uma sociedade atuam ideologicamente, criando e mantendo relações de dominação de indivíduos sobre outros, permitindo ou não o acesso a bens, sejam culturais ou materiais. Uma vez que "as formas simbólicas, ou sistemas simbólicos, não são ideológicos em si mesmos: se eles são ideológicos, e o quanto são ideológicos, depende das maneiras como eles são usados e entendidos em contextos sociais específicos." (THOMPSON, 2002, p.17)

A ideologia não deve ser entendida como uma prática qualquer, uma vez que ela é utilizada para criar ou manter relações desiguais e injustas, ou seja, para "se referir às maneiras como o sentido (significado) serve, em circunstâncias particulares, para estabelecer e 
sustentar relações de poder que são sistematicamente assimétricas" (THOMPSON, 2002, p.16).

Kellner (2001) propõe que assim como a cultura, em seu sentido mais amplo, auxilia no processo de modelagem do individuo, a cultura da mídia também cumpre esse papel. Uma vez que ela passa a conduzir a vida cotidiana, na medida em que os indivíduos permanecem um grande período de seu tempo participando de diferentes formas de cultura, que são difundidas pelos meios de comunicação, como ouvir música, freqüentar cinemas, assistir televisão, dentre diversas outras.

Nessa cultura vinculada pela mídia são produzidos novos modelos de identificação, estilo, moda e comportamento, partindo de modelos e imagens de personalidades ou celebridades criadas pela própria mídia.

Não obstante, Kellner (2001) assinala que através da sociedade voltada para o consumo e predomínio da mídia, a identidade vem sendo cada vez mais vinculada á aparência pessoal, ou seja, á produção de uma imagem, sendo que muitos desses modelos e estilos provêm da própria cultura da mídia. Ele declara que:

Há uma cultura veiculada pela mídia cujas imagens, sons e espetáculos ajudam a urdir o tecido da vida cotidiana, dominando o tempo de lazer, modelando opiniões políticas e comportamentos sociais, e fornecendo o 
material com que as pessoas forjam sua identidade. $\mathrm{O}$ rádio, a televisão, o cinema e os outros produtos da indústria cultural fornecem os modelos daquilo que significa ser homem ou mulher, bem-sucedido ou fracassado, poderoso ou impotente. A cultura da mídia também fornece o material com que muitas pessoas constroem o seu senso de classe, de etnia e raça, de nacionalidade, de sexualidade, de "nós" e "eles". Ajuda a modelar a visão prevalecente de mundo e os valores mais profundos: define o que é considerado bom, mau, positivo ou negativo, moral ou imoral. As narrativas e as imagens veiculadas pela mídia fornecem os símbolos, os mitos e os recursos que ajudam a constituir uma cultura comum para a maioria dos indivíduos em muitas regiões do mundo de hoje. (KELLNER, 2001, p. 9).

Por isso, é fundamental analisar de forma crítica a maneira como a mídia se empenha em reiterar as relações de dominação e opressão, através de articulações de posições ideológicas específicas, servindo aos interesses das forças e elites de poder.

\section{A MASSIFICAÇÃO DA TELEVISÃO}

Dentre diversos meios de comunicação, o que mais se destaca é a televisão. Devido sua difusão massiva, a televisão pode ser considerada um dos mais poderosos artefatos culturais midiáticos surgidos a partir da segunda metade do século XX e "os meios mais 
importantes de difusão são os que têm a ver com a transmissão televisiva [...]" (THOMPSON, 2002, p. 25).

Desde a origem da televisão, podemos notar marcadamente uma grande alteração tanto no perfil cultural quanto sociológico das populações. Ela tem desempenhado uma importante função na promoção informativa e cultural, ao propagar informação sobre outros povos e outros modos de vida, proporcionando assim facilidade de acesso às informações, que passaram a estar ao alcance dos nossos olhos em segundos, mesmo estando do outro lado do mundo.

Segundo Rondelli, “(...) a televisão agrega audiência e se estabelece como forma comunicativa de angariar legitimação e de se lançar como protagonista privilegiada com grande poder de desempenho na construção de valores públicos e de uma determinada ética (1997, p. 155)".

Um dos pontos que fez da televisão um dos maiores artefatos culturais midiáticos da atualidade é o fato de que as mensagens audiovisuais demandam mínimo envolvimento e empenho por parte de seu receptor.

A televisão, este dispositivo discursivo que muito pode conter e contar, estabelece outras estratégias, estas não propriamente entre os textos ficcionais e jornalísticos, localizadas numa região propositadamente obscura: são as 
inserções publicitárias ou político-promocionais que se escamoteiam como tais nos discursos apresentados, a princípio, como jornalísticos - cujo compromisso seria o de apresentar informação, a mais objetiva, sobre a realidade. Tais inserções que, por vezes, também aparecem em textos ficcionais se utilizam de uma certa atitude despretensiosa e despreocupada do telespectador para, literalmente, venderem opiniões e informações. Uma estratégia de usar, ou abusar, da confiabilidade depositada pelo receptor ao que lhe é apresentado para lhe dirigir informações de natureza e objetivos duvidosos quanto à sua veracidade, embora revestidos com tal verniz (RONDELLI, 1997, p. 158).

De acordo com Penteado (2000), a televisão enquanto um canal de comunicação sócio-cultural produz ações que visam à mobilização do público e também atua promovendo a difusão dos bens simbólicos através de sua programação. Sua produção encontra-se a serviço do sistema social em que está inserida, baseando-se em numa doutrina social ou ideologia do sistema dominante.

Ainda, segundo Penteado (2000), através de sua linguagem, este instrumento de informação possibilita estabelecer comportamentos e valores, demonstrando as diversidades culturais e por diversas vezes, assumindo o papel de mediador entre o sujeito e o mundo.

E por estar inserida numa sociedade orientada pela ética capitalista, a televisão veicula através de suas transmissões princípios e valores inerentes a este sistema, como por exemplo, o materialismo, a 
competição, o consumismo, dentre outros. Além disso, ela, enquanto produção simbólica pode estar trabalhando em função de grupos sociais e raciais determinados. Dessa maneira,

além de ser um caso exemplar dos mecanismos de reprodução das relações raciais, a mídia desempenha um papel central e único na produção e manutenção do racismo. Através de meios de comunicação, especialmente dos meios de comunicação de massa, como a televisão e o rádio, as desigualdades raciais são naturalizadas, banalizadas e muitas vezes racionalizadas. Em grande medida, através da mídia de massa as representações raciais são atualizadas e reificadas. (RAMOS, 2002, p. 09).

Muito além de ser apenas um meio de comunicação ou um veículo que transmite informações, a televisão tem assumido cada vez mais o papel de agente de produção social, por isso, torna-se tão importante entender quais as imagens do negro que são apresentadas na televisão. Para tanto, a seguir será realizada uma sucinta análise dessa questão na mídia brasileira. 


\section{A QUESTÃO DO AFRODESCENDENTE NA TELEVISÃO BRASILEIRA}

Assim como ocorreu em todo processo histórico brasileiro, o lugar do no que se refere à mídia, negro também não foi considerado demonstrando que as "aparências no Brasil correspondem à realidade, temos pouco acúmulo entre artistas e lideranças políticas e culturais no desenvolvimento de estratégias alternativas próprias na televisão brasileira e de confronto com a discriminação racial". (ARAUJO, 1996, p.243).

Com isso, esse quadro de desigualdade entre os grupos étnicoraciais negros e brancos é bastante acentuado, principalmente, no que se refere às representações desses grupos na mídia, tornando-se fundamental analisar a questão do negro dentro da perspectiva não somente midiática, mas principalmente televisiva brasileira.

Na sociedade da imagem em que vivemos, e com o nível de domínio alcançado pelas redes de TV sobre outros meios audiovisuais no Brasil, a televisão tornou-se o nosso mais poderoso espelho, a nossa janela para a realidade cotidiana. Nela, o telejornal apresenta o pretenso real e a telenovela traz a representação e os desejos da alma nacional. Entretanto, nessa realidade eletrônica, na qual só existe quem tem sua imagem espelhada em si, os negros vêem negada a sua história, os seus desejos e os 
seus sentimentos. Nessa janela, os negros só podem aparecer (como na experiência norte-americana) na perspectiva que os mitos brancos têm da sua realidade e das suas experiências e nas percepções e imperativos econômicos dos produtores e patrocinadores brancos. Por outro lado, os negros sempre estiveram presentes na história da TV do cinema brasileiro, mas sempre representados por estereótipos e clichês negativos, como elementos de diversão para uma audiência com um pretenso imaginário eurocêntrico e não para uma cultura nacional fortemente influenciada por seu grupo étnico. (ARAUJO, 1996, p.247).

Conforme dados levantados por Silva e Rosemberg (2007) mesmo que a televisão brasileira possa ter reduzido a percepção social em relação á discriminação racial (Costa, 1988; Leslie, 1995), os negros permanecem sub-representados em publicidades e propagandas televisivas (Hanselbag, 1988; Baccega e Couceiro de Lima, 1992; Data folha, 1995; Leslie, 1995; Araujo 2000; Oliveira, 2004).

Segundo Van Djik (2008), a maior parte das análises relacionadas ao racismo concentra-se em modos de desigualdade socioeconômica e exclusão e/ou atitudes e preconceito étnicos raciais. Entretanto, mesmo sendo essenciais, tais exames não são capazes de explicar as diversas procedências do racismo e nem dos métodos de suas reproduções no dia-a-dia. E mesmo concordando que o racismo na América Latina foi arraigado pelo colonialismo e pelas formas de 
dominação (econômica, social e cultural) executadas pelas elites brancas, o autor questiona o fato de que:

Já que o racismo não é inato, mas apreendido, deve haver meios para esse processo de aquisição ideológica e prática. As pessoas aprendem a ser racistas com seus pais, seus pares (que também aprendem com seus pais), na escola, com a comunicação de massa, do mesmo modo que com a observação diária e a interação nas sociedades multiétnicas. (Van Djik, 2008, p.15).

Van Djik (2008) aponta que tais processos de aprendizagem são amplamente discursivos, ou seja, baseados e apreendidos através de formas de textos e falas presentes nos mais variados eventos comunicativos, como livros, programas de televisão, cinema, jornal, dentre outros. Dessa forma, muitas práticas de racismo cotidiano até podem ser aprendidas por meio da observação ou imitação, porém, mesmo estas necessitam ser legitimadas, explanadas ou amparadas discursivamente.

Esses discursos racistas, conforme assinala Van Djik (2008), são vastamente assimilados e reproduzidos através do discurso dominante, disseminado através das elites simbólicas brancas, ou seja, um grupo composto por pessoas brancas que detém grande poder de 
influencia, como por exemplo, jornalistas, políticos, escritores, pesquisadores, dentre outros.

Além disso, Van Djik (2008) observa que a maior parte dos grupos dominantes aprende a ser racistas em virtude desses processos comunicativos. Aliás, o conhecimento que esses grupos possuem (ou acreditam possuir) no que se refere à etnia dos Outros foram formuladas através dos mais diversos discursos. E através disso, sobre esse pilar, são estabelecidos conceitos e posturas, que fazem com que a maioria dos elementos de um grupo específico reproduza um status quo étnico, assumindo um consenso do grupo através das ideologias dominantes que os legitime (a menos que existam boas razões para desacordarem com o grupo).

Van Djik (2008) ressalta que esse processo não é determinante e nem acontece automaticamente, cada elemento participante de um determinado grupo possui relativa liberdade de admitir ou não os discursos dominantes e suas ideologias subjacentes. Existe a possibilidade de desenvolverem atitudes diferentes, visando $o$ desenvolvimento de uma ideologia alternativa, que seja não racista e anti-racista.

Todavia, conforme assinala Giroux (1999), as mídias eletrônicas, como televisão, cinema, música e notícias, tornaram-se 
importantes armas pedagógicas atuando no condicionamento do imaginário social do indivíduo, na forma como modela a visão que se tem de si mesmo, da sociedade e dos outros. No cerne dessa influência da mídia, está a política de representação da raça onde abstrai as histórias reais dos negros, "ao mesmo tempo reforçando todos os estereótipos demasiado familiares que vão do preguiçoso e imóvel ao ameaçador e perigoso". (GIROUX, 1999, p 114).

De acordo com os apontamentos de Giroux (1999), um dos motivos que levaram ao "novo racismo" no EUA na década de 1980, foi causado devido às maldosas representações da negritude, demonstrando inferioridade em relação aos nativos, fato que conquistou uma aceitação progressiva na mídia dominante. De forma que:

Codificação racial, exibida na forma de populismo de senso comum, associava o negro a uma série de equivalências negativas que contradiziam a injustiça racial, ao mesmo tempo afirmando o inconsciente racista reprimido e indescritível da cultura branca dominante. Imagens ameaçadoras da juventude negra, de mães sob a tutela do bem-estar social e de condenados, forjadas pela retórica evocativa de jornalistas semeadores do medo, ajudavam a sustentar a imagem de uma família branca de classe média de subúrbio, sitiada e ameaçada [...]. (GIROUX, 1999, p 101). 
No Brasil essa representação do negro e do branco na mídia ocorreu de forma distinta da estadunidense. Segundo Araújo (2004), no contexto brasileiro, o Estado buscou apagar as diferenças étnico-raciais através de uma construção de identidade brasileira, utilizando o mito da democracia racial e das teorias da miscigenação que idealizavam o branqueamento da nação, conforme já estudado no decorrer desse trabalho. Já nos EUA foi empregada uma "diferenciação étnica para conferir um estatuto de superioridade à raça dominante". (ARAUJO, 2004, p.35).

Através de análises realizadas por Silva \& Rosemberg (2007), por meio da consulta de textos publicados entre 1987 e 2002, presentes em 24 bases de dados bibliográficos, foi possível verificar o racismo na mídia, por tipo e meio discursivo entre os anos de 1987-2002. A pesquisa, proposta pelos autores focou em diversos campos, como o da literatura e cinema, imprensa, televisão, literatura infanto-juvenil e livro didático. 
Revista Vernáculo, $n^{\circ} 28,2^{\circ} \mathrm{sem} / 2011$

Tabela 1 - Pesquisas brasileiras sobre racismo na mídia, por tipo e meio discursivo (1987-2002).

\begin{tabular}{|c|c|c|c|c|c|c|c|}
\hline $\begin{array}{c}\text { Meio } \\
\text { Discursivo }\end{array}$ & Total & Dissertações & Teses & Livros & $\begin{array}{c}\text { Capítulos } \\
\text { em } \\
\text { Livros }\end{array}$ & $\begin{array}{c}\text { Artigos } \\
\text { em } \\
\text { Revistas }\end{array}$ & $\begin{array}{c}\text { Artigos } \\
\text { em } \\
\text { Anais }\end{array}$ \\
\hline $\begin{array}{c}\text { Livros } \\
\text { didáticos }\end{array}$ & 47 & 13 & 3 & 3 & 10 & 14 & 4 \\
\hline Jornais & 16 & 6 & 2 & 2 & 2 & 6 & 2 \\
\hline Rádio & 1 & - & - & 1 & - & - & - \\
\hline Televisão & 11 & - & 1 & - & 2 & 6 & 2 \\
\hline Cinema & 4 & - & - & 3 & - & 1 & - \\
\hline Publicidade & 6 & - & 1 & - & 1 & 3 & 1 \\
\hline $\begin{array}{c}\text { Mídia em } \\
\text { geral }\end{array}$ & 6 & - & - & 2 & 1 & 3 & - \\
\hline Literatura \\
e Poesia
\end{tabular}

FONTE: Silva \& Rosemberg, 2007, p.76. 
Através da referida pesquisa, Silva \& Rosemberg (2007) organizaram os resultados encontrados na investigação utilizando a revisão de literatura acerca do discurso racial na mídia brasileira em quatro pontos:

a) a manifesta sub-representação do negro nas mais diferentes mídias;

b) o permanente silenciamento por parte das mídias em relação às desigualdades raciais.

c) a consideração do branco como padrão universal de humanidade, sendo colocado como representante natural da espécie.

d) a estereotipização na representação do negro na mídia.

No contexto brasileiro o que aconteceu foi uma invisibilidade do negro brasileiro nos meios de comunicação, limitando a presença destes ao máximo, além de quando estes eram representados, isso ocorria de forma estereotipada, colaborando na difusão e perpetuação de idéias racistas. E mesmo

[...] passados mais de cem anos do início do movimento eugenista, negros e índios continuam vivendo as mesmas compulsões desagregadoras de uma auto-imagem depreciativa, gerada por uma identidade racial negativa e reforçada pela indústria cultural brasileira, a qual insiste simbolicamente no ideal de branqueamento, sendo um dos seus corolários o desejo de euro-norte-americanização [...]. (ARAÚJO, 2004, p.25). 
Outro ponto, é que no Brasil, a branquidade é olhada não apenas como um valor de normalidade, mas também como um padrão estético, idealizado e buscado por muitas pessoas, de várias faixas etárias, ou seja, de crianças a idosos. Esse padrão estético não se destaca apenas em virtude de ser uma norma social amplamente desenvolvida e cultivada em nossa sociedade, mas também pelo fato de que os discursos midiáticos que apresentam mais acesso estabelecem modelos de pessoas "perfeitas", ou seja, brancas.

Essa produção e reprodução das formas simbólicas estão ocorrendo através da [...] midiação da cultura moderna - isto é, as maneiras como as formas simbólicas, nas sociedades modernas, tornaram-se crescentemente mediadas pelos mecanismos e instituições da comunicação de massa [...]. (THOMPSON, 2002, p. 104).

De acordo com Silva \& Rosemberg (2007), a mídia, ao produzir e veicular discursos que naturalizam e ressaltam a branquidade normativa, contribuem na produção e reprodução de um racismo estrutural e simbólico da sociedade. Esse fato ocorre na medida em que os atributos imputados aos brancos sejam biológicos ou étnicos, são negados tanto aos negros quanto às pessoas mestiças de pele mais escura de forma veemente. E mesmo que estas pesquisas, realizadas 
pelos autores, demonstrem algumas modificações nos discursos midiáticos sobre negros, isso ainda ocorre de forma muito tímida.

Utilizando tais discursos nas produções culturais, o racismo brasileiro não apenas se mantém, mas atua como produtor e reprodutor de desigualdades sociais tanto no plano estrutural quanto simbólico na sociedade brasileira, já "que produz e veicula um discurso que naturaliza a superioridade branca, acata o mito de democracia racial e discrimina os negros". (SILVA e ROSEMBERG, 2007, p. 74).

Empregando o exame acerca do papel da mídia na história da telenovela brasileira, Araújo (2004) demonstra como os negros foram representados e as consequiências dessas representações nos contexto construtivo da identidade do povo brasileiro.

Segundo análises realizadas por Araújo (2004), que pesquisou 98 novelas produzidas pela TV Tupi, TV Excelsior e Rede Globo, entre os anos de 1963 a 1997. Com exceção das novelas que tinham como tema a escravidão, "não foi encontrado nenhum personagem afrodescendente em 28 delas e em apenas em 29 telenovelas o número de atores negros contratados conseguiu ultrapassar a marca de dez por cento do total do elenco". (ARAÚJO, 2004, p.305).

Araújo (2004) demonstra como nestes folhetins os papéis imputados os negros foram apresentados de forma estereotipada, 
subalterna e negativa, destacando-se os aspectos da "malandragem" ou da sensualidade, no caso das mulheres mais novas, além de que as mulheres mais velhas, sempre colocadas em papéis de criadas e mães pretas.

Além disso, na pesquisa intitulada "Onde está o negro na TV pública" realizada pela Fundação Cultural Palmares e coordenada por Joel Zito Araújo, foram analisadas pelo período de uma semana as programações transmitidas pelos canais TV Cultura, TVE Brasil e TV Nacional, que fizesse qualquer menção à visibilidade negra. E chegou a conclusão de que ao todo, apenas $0,9 \%$ da grade horária desses canais são voltadas para a cultura afrodescendente, sendo que $82 \%$ da grade horária, não abordam, de nenhuma forma, assuntos relacionados a negros ou indígenas.

Igualmente, outra parte da pesquisa quantificou o número de apresentadores e jornalistas, que fazem parte da programação, e que sejam índio ou afrodescendentes, ficando constatado que 9,4\% dos apresentadores e 6,7\% dos jornalistas são negros ou indígenas.

No que se refere ás produções voltadas ao público infantil, Saldanhas (2012) ao analisar os programas infantis transmitidos pela rede Globo de televisão entre 1986 e 2011, constatou que dos 10 programas pesquisados, apenas 5 deles havia personagens fixos afro- 
descendentes. Quando analisado em termos de quantidade, nesse período de um total de 90 personagens fixos (humanos) que existiram na grade da programação infantil da TV Globo apenas 9 eram negros ou pardos. Isso significa que somente de $10 \%$ dos personagens ou atores eram afrodescendentes.

Tais números demonstram que a produção televisiva brasileira forneceu aparatos suficientes para a manutenção de uma branquidade normativa, através de exaltações às características estéticas eurodescendentes. Além do mais, esta falta de pluralismo cultural apresentado na mídia brasileira, seja pelas televisões comercias ou pelas públicas, atinge também a auto-estima de negros e índios, uma vez que estes não são representados na televisão.

$\mathrm{Na}$ televisão, a diversidade cultural e racial brasileira "transmuta-se em um Brasil branco, desrespeitando os anseios históricos não só das entidades culturais, políticas e religiosas negras, como também das nações indígenas" (ARAUJO, 2004, p.307).

No Brasil, como é de conhecimento geral, as TVs comerciais e públicas não têm respeito pela maioria afrobrasileira. Não tem programação voltada para atendimento especifico dos seus valores, necessidades e história não têm negros nos altos cargos executivos e nem mesmo nas direções intermediárias, e não estão submetidas a nenhum tipo de controle desse imenso grupo étnico. (ARAUJO, 1996, p.246). 
Apesar disso, entre as décadas de 1980 e 1990, Araújo (2004) aponta que ocorreram algumas mudanças, certamente resultantes das ações e criticas do movimento negro, nas telenovelas brasileiras, como por exemplo, negros como protagonistas e discussões acerca do racismo, sendo este período considerado pelo autor como um momento de ascensão do negro.

Todavia, ainda vigorava (e vigora) a ideologia da branquidade na sociedade brasileira, onde as imagens dominantes, "carregam, como subtextos, reforçam o elogio dos traços brancos como o ideal de beleza para todos os brasileiros". (ARAUJO, 2004, p.306).

Tal fato é possível observar não somente em relação á quantidade de atores, apresentadores e personagens afrodescendentes que estão na mídia, mas também a partir das posições que eles ocupam dentro dela, uma vez que é raro perceber uma imagem de afro-brasileiro no mundo midiático, imagens positivas então, são mais difíceis ainda. Quando são retratados, os afrodescendentes estão atuando em papéis de criados, domésticos, novelas da época da escravidão, dramas sociais, dançarinos, músicos, esportistas, comediantes ou mesmo serviçais. 


\section{CONSIDERAÇÕES FINAIS}

Ao analisar tais aspectos da televisão brasileira, podemos perceber que mesmo após tanto tempo, na telenovela e porque não dizer, na mídia brasileira em geral, o lugar do negro não se alterou significativamente e ideais, como o branqueamento, permanecem sendo reproduzidos ainda na contemporaneidade.

E através dessa rejeição da negritude e promoção da branquidade, através de modelos de estética calcada nas concepções branca de mundo, as imagens televisivas "continuam confirmando a vitória simbólica da ideologia do branqueamento e da democracia racial brasileira". (ARAÚJO, 2004, p.38).

Dessa forma, é possível considerar que os programas televisivos e a mídia em geral contribuem significativamente para a consolidação de uma branquidade normativa, onde os brancos são escolhidos para representar o ideal de beleza do povo brasileiro, colaborando para que se perpetue uma estética produzida pela persistência da ideologia do branqueamento em nossa sociedade.

No entanto, é nosso papel, enquanto pesquisadores, apontarmos tais questões, propondo debates que possam auxiliar na 
Revista Vernáculo, $n^{\circ} 28,2^{\circ}$ sem/2011

construção de uma mídia mais igualitária, que demonstre a verdadeira diversidade do povo brasileiro. 


\section{REFERÊNCIAS}

ADORNO, T.W.; HORKHEIMER, M . Dialética do esclarecimento. Trad. Guido Antonio de Almeida. Rio de Janeiro: Zahar, 1985.

ADORNO, Theodor W. Sociologia. Org. e trad. por Gabriel Cohn. São Paulo: Ática, 1986.

ARAÚJO, Joel Zito. A negação do Brasil: o negro na telenovela brasileira. São Paulo: Editora, Senac, 2004.

BELLONI, Maria Luiza. O que é Mídia-Educação? . Campinas, SP: Autores Associados, 2001.

GIDDENS, Anthony. As consequências da modernidade, trad. de Raul Fiker. São Paulo: Editora Unesp, 1991.

GIROUX, Henry A. Por uma pedagogia e política da branquidade. Cadernos de Pesquisa, São Paulo, n. 107, p. 97-132, jul. 1999.

KELLNER, Douglas. A cultura da mídia. São Paulo: EDUSC, 2001.

PENTEADO, Heloísa Dupas. Televisão e escola: conflito ou cooperação. São Paulo: Cortez, 2000. 
Revista Vernáculo, $n^{\circ} 28,2^{\circ}$ sem/2011

RAMOS, Silvia (org.), Mídia e Racismo. Rio de Janeiro, Pallas, 2002

RAMOS, Silvia; MUSUMECI, Leonarda. Elemento Suspeito: Abordagem policial e discriminação na cidade do Rio de Janeiro. Rio de Janeiro: Civilização Brasileira, 2005.

RONDELLI, Elizabeth. Realidade e ficção no discurso televisivo. Revista Letras, n 48 (jul/97). Curitiba, UFPR, p. 149-161, 1997.

ROCHA, José Geraldo da. De preto a afro descendente: implicações terminológicas. Almanaque CIFEFIL. , v.XIV, p.899 - 907, 2010.

SALDANHAS, V.R.D. Infâncias Marcadas Pela Branquidade: Uma Análise De Conteúdo Dos Programas Infantis Da Rede Globo De Televisão Entre 1986 E 2011. 86 f. Monografia (Bacharelado e licenciatura em Ciências Sociais) - SETOR DE CIÊNCIAS HUMANAS, LETRAS E ARTES-SCHLA DEPARTAMENTO DE CIÊNCIAS SOCIAIS-DECISO.Curitiba, 2012. Disponível em: <http://www.humanas.ufpr.br/portal/cienciassociais/files/2012/06/Mon ografia-Viviane-Darif.pdf > . Acesso em:17.ago.2013 
Revista Vernáculo, $n^{\circ} 28,2^{\circ} \mathrm{sem} / 2011$

SILVA, P. V. B.. Racismo em livros didáticos: estudo sobre negros e brancos em livros de Língua Portuguesa. 1. ed. Belo Horizonte: Autêntica, 2008.

SILVA, P. V. B.. Racismo discursivo na mídia brasileira. In: VI Congresso Latinoamericano de Estudios del Discurso, 2005, Santiago. Anales do VI Congresso Latinoamericano de Estudios del Discurso. Santiago : Associación Latinoamericana de Estudios del Discurso, 2005.

SILVA, P. V. B.; ROSEMBERG, F. Negros e brancos na mídia brasileira: discurso racista e práticas de resistência. In: Teun van Dijk. (Org.). Racismo e discurso na América Latina. São Paulo: Contexto, 2007. 